\title{
Conditions of the Implementation of Selected Early Prevention Behaviours by High School Students from Radom
}
Authors' contribution:
A) conception and design of the study
B) acquisition of data
C) analysis and interpretation of data
D) manuscript preparation
E) obtaining funding

\author{
Jolanta Mogiła-Lisowska ${ }^{\mathrm{A}, \mathrm{D}, \mathrm{E}}$, Beata Bukowska ${ }^{\mathrm{B}, \mathrm{C}}$ \\ Josef Pilsudski University of Physical Education in Warsaw, Poland
}

ABSTRACT

The specific type of human activities that aim to maintain full health by maintaining biological, psychological and social comfort indicate the need to adopt a holistic perspective in any analysis of determinants of pro-health behaviour. When analysing the aetiology of somatic diseases, it is important to take into account biological and mental well-being as well as the connections between needs, interests and lifestyle decisions and their consequences. One of the measures used to reduce the risk of a progressive lack of immunity to non-infectious diseases is prevention, understood as actions aimed at preventing diseases or other adverse health phenomena by controlling their causes and risk factors. An important component of prevention programmes is preventing the occurrence of negative social behaviour patterns that contribute to the increased risk of diseases. Three basic components of a healthy lifestyle - regular physical activity, proper nutrition and sufficient rest and relaxation (stress management) - justify the importance of practising healthy habits from an early age. The role of promoting pro-health behaviours among children and adolescents is of particular importance in the context of increasingly sedentary lifestyles, obesity and weight problems.

The aim of this study is to analyse the determinants of physical activity and a balanced diet in the lifestyle of high school students in Radom aged 16-19. The study was conducted in 2013 at VII Krzysztof Kamil Baczyński High School in Radom and involved 140 students. The results of the study indicate that only one-third of respondents fulfilled the requirements for minimal physical activity for their subjective and objective needs of this phase of ontogenetic development, such as being in the company of their peers, spending time in open air and taking care of their physical fitness. Unfortunately, the majority of the parents of the surveyed high school students, who were at the time about 40 years old, did not engage in any systematic physical activity. In other words, the family environment of the studied young people did not promote patterns of physical activity. Similarly, healthy nutrition in the study group was lacking. Both the boys and girls ate around five meals a day, but many respondents snacked between meals on sweets and crisps. The majority of students drank water. The vast majority of them ate their meals at home, ensuring that their meals were freshly prepared and not pre-cooked.

Although school children prefer to spend time with their peers, the family is still a point of reference in terms of values and ways of spending free time. The authors of this paper must take into account the minimal impact of the family on choices regarding physical activity. The studied group of high school students demonstrated 
a lack of preventive care for their health and did not have a well-established systematic approach to physical activity and healthy eating habits.

KEYWORDS prevention behaviours, high school students, healthy nutrition, physical activity

\section{Introduction}

The specific type of human activities that aim to maintain full health through maintaining biological, psychological and social comfort indicate the need to adopt a holistic perspective in any analysis of determinants of pro-health behaviour (Carlsson, Andersson et al., 2007, p. 255). When analysing the aetiology of somatic diseases, it is important to take into account the mind-body connection from the perspective of mental factors, as well as the connections between needs, interests and lifestyle decisions and their consequences (Bernstein, Morabia, \& Sloutskis 1999, p. 863; Fletcher, Balady, Amsterdam et al. 2001, p. 1700; Garza, Ha, Garcia et al. 2004, pp. 209-220). Modern times are forcing the acquisition of skills to remedy the increasingly difficult challenges related to the need to adapt to the changing conditions of life. Such skills are associated with widely understood pro-health activities, though they are also related to activities that modify quality of life by encouraging proactive health-related attitudes (Oja, 2001, p. 428; Varo, MartinGonzalez, de Irala-Esteves et al., 2003, p. 138).

A characteristic feature of modern human activities in many areas of behaviour is continuous diagnosis and the monitoring of the effectiveness of these activities. Another significant feature in this respect includes the globalized effects of socio-economic development: the environment's impact on humans, such as minimizing people's physical activity levels (as defined by S. Kozłowski and K. Nazar, 1995), as well as leisure physical activity (see J. Mogiła-Lisowska, 2010), the pressure of many factors in limited time and space, and ultimately the haste and lack of rationality in nutrition all contribute to the progressive loss of the body's immune defences. Environmental factors also force changes in the behaviour of individuals and entire populations (Lichtenstein, Appel, Brands et al. 2006, p. 2191; Wartburton, Nicol, Bredin 2006, pp. 962-964).

These changes have a negative impact on the health and quality of human life. One of the measures that must be taken reduce the risk of a progressive lack of immunity to non-infectious diseases is prevention, understood as actions that aim to prevent certain diseases or other adverse health phenomena by controlling their causes and risk factors. An important component of prevention is the avoidance of negative social behaviour patterns that contribute to increasing the risk of disease (Handbook for Canada's Physical Activity Guide to Healthy Living. Health Canada, Ottawa, 1998).

The importance of lifestyle increases with time, as do the variables of individual behaviour as factors determining overall health. This in turn forces the necessity of shaping pro-health behaviours, promoting a healthy lifestyle and practicing the early prevention of diseases, especially non-infectious diseases, as confirmed by the study of B. K. Pedersen and B. Saltin (2006, pp. 4-60).

According to the World Health Organisation (WHO), early prevention applies to healthy people and consists of perpetuating the correct patterns of a healthy lifestyle and the prevention of the spread of behavioural patterns that are detrimental to health. In short, early prevention is conducive to the accumulation of a maximum resource of the biological energy of the system. Early prevention results in a reduction of morbidity in different periods of time by reducing the risk of disease (Books et al., 2006).

"Prevention is different from other counteracting measures because it consists in actions which are taken before the negative phenomena emerge or spread, and their severity forces the use of remedies". (Szymańska et al. 2002, p. 19)

The European Union conducted a study on young people's lifestyles and sedentariness (Universität Paderborn [2004]: Study on lifestyles and trends favouring sedentariness among young people and the role of 
sport in the context of education as activities restoring the appropriate balance). The final report was compiled by W-D. Brettschneider, R. Naul et al. (http://ec.europa.eu/sport/documents/lotpaderborn.pdf).

The study shows that the role of promoting healthy behaviours among children and adolescents is of particular importance in the context of the growing trend of sedentariness, obesity and weight problems, which has also been reported by numerous studies outside of Europe (Bigddle, Sallis, \& Cavill, 1998, pp. 21-46; Prochaska, Sallis, \& Long, 2001, pp. 554-559; Leon, Rodriguez-Perez, Rodriguez-Benjumeda et al., 2007, p. 244). Not engaging in the minimum healthy amount of physical activity and consequently carrying excess weight or becoming obese leads to a number of non-infectious diseases.

Other studies, such as the HBSC (Health Behaviour in School-Aged Children) study (2016), indicate the relationship between time spent watching television in childhood and later obesity. The studies of the Harvard School of Public Health in Cambridge on the correlation between time spent watching television and obesity show that obesity occurs five times more frequently in children who spend five instead of two hours a day watching television (Murray, Lopez et.al., 2006).

Obese youth are at risk for many systemic diseases, such as circulatory diseases, metabolic disorders, diabetes and disorders of the motor system. The most common cause of obesity is excess energy value of food consumed relative to body needs. Physical activity and its thermogenic properties may be a way to counteract the above. Physical activity also improves muscle tissue, which is responsible for the condition of the spine (Grzywacz, 2011; Jakicic, \& Otto, 2006, pp. 59-60).

Physical activity is one of the basic and primary human needs, and a satisfactory amount of physical activity leads to a balance between the dual nature of the human being in its biological and social dimension. It aids in development during childhood and adolescence. Physical activity is the most common and most versatile means of stimulating the development of children and youth. In addition, sport as a favourite form of leisure has socially preventive and rehabilitative functions. It also has a considerable impact on quality of life, which is confirmed by the research of D. Warburton, C. W. Nicol and S. Bredin (2006, p. 961-974), among other studies.

The physical activities of children and young people shape not only their motor development, but also the activity of the whole young body. According to Z. Chromiński, the biological sphere shapes a healthy, efficient individual who is physically resistant to adverse environmental influences. The results of many studies show that "increased physical activity is beneficial to a number of qualities, not only physiological, but also related to immunity, adaptation and the correct course of a number of metabolic and hormonal processes of a growing organism" (Chromiński, 1987, p. 17). Movement beneficially affects the "mineralization of bones, increases the mass of active tissues of the body and decreases the amount of body fat, which is important in the prevention of obesity" (Chromiński, 1987, p. 17; Manson et al., 2004, p. 164). Thus, ensuring the adequate physical activity of young people provides them with the appropriate methods to take care of themselves, as well as the potential to protect their own health.

The impact of physical activity facilitates the achievement of a number of necessary characteristics, such as emotional balance, the ability to cope with stress and the ability to adapt to changing conditions. In addition, it shapes the feeling of responsibility and helps to assimilate social norms and cultural values.

The appropriate level of physical activity in adolescents fulfils their needs of movement and stimulates development. Each young person has individual needs in this respect that are dependent on gender, material status, health status, level of physical fitness and genetic factors (Drabik, 1995; Wing, 1999, p. 552).

The importance of the leisure physical activity of parents is pointed out by many researchers (including Drabik, 1995; Kalecińska, 2005; Sadowska, 1992; Wadden, Butryn, \& Wilson, 2007, pp. 2229-2235).

Abilities associated with physical movement acquired in childhood play a large role in the future life of young people: they affect their behaviour and attitude towards physical activity. Young people prefer to spend time with their peers, but the family is still a point of reference in terms of values and ways of spending free time. The process of socialization is shaped by a wider group as people get older. The success of the 
socialization of physical activity depends mainly on whether the socialized individual will come to hold the belief that participation in physical activity is a general social norm (Dziubiński, \& Krawczyk, 2011).

As W. Srokosz (2002, p. 111) commented, sport, especially that played in school, has significant educational values, but only if its teachers are aware of this fact and are able to make sport a personalitybuilding pursuit. A child's school years are a time of great mental plasticity characterized by an honest sensitivity that can be put to good use. Activities in the field of physical education are an important element contributing to shaping students' beliefs about their own health, development, entertainment or education. Many studies have shown that what is dominant in this respect is the educational atmosphere of the school. The effectiveness of school work, according to M. Bukowiec (2009, p. 326), depends on the quality of the entire environment, that is, educational, physical, economic, natural and organizational factors which impact children with different dynamics, variability and strength. What is important for physical education is the material conditions and the space in which the school functions, the pedagogical awareness of parents and their economic and cultural status, the availability of infrastructure for sport and recreation and how institutions and organizations promote sport and recreation. According to B. Królikowska (2002, p. 165), modern schools and homes should pay more attention to matters related to the sport and leisure activities of children and young people, including shaping the desired habits and needs of a healthy lifestyle. Inequalities in access to sport, especially in economically disadvantaged environments, are noted by H. Sozański (2003, p. 49), who has observed low levels of physical fitness in children and young people, increased risks of pathological behaviours and increases in phenomena such as drug addiction, alcoholism and crime where an attractive, valuable educational offer is lacking. As T. Maszczak has discovered (1995, p. 88), approximately $40 \%$ of children require active medical treatment, and $80 \%$ of children and adolescents have posture defects. A large part of these conditions result from the insufficient participation of children and young people in physical activity. Physical activity, in the words of the author, is a form of disease prevention, especially for obesity and diseases of the cardiovascular system (Jakicic, Otto, Polizien et al., 2007; Van Baak, \& Saris, 2005), as well as musculoskeletal diseases and posture defects.

The three basic components of pro-health behaviours, regular physical activity, proper nutrition and proper rest and relaxation (stress management), prove the importance of developing healthy habits from an early age. All of these have their pattern-making origins in the environment of primary socialization, and, along with human development, they are also shaped by the school environment, work and family.

Another important factor for the development of young people is rational nutrition. Proper nutrition is essential for the development of the physical and mental health of children and adolescents. Along with appropriately implemented physical activity, it contributes to the specific balance of the young body. Environments which develop a culture of nutrition and leisure physical activity have similar goals. Factors such as a lack of support in the home environment, a lack of access to health education, peers who often share their unhealthy dietary habits, or antisocial, unhealthy free time behaviour also play an important role in the implementation of appropriate nutritional and physical activity patterns.

Being overloaded with school duties or extracurricular activities and living a fast-paced life also has an influence on unhealthy eating habits. In general, food consumed by those who choose this lifestyle has a high calorific value (from carbohydrates and fats) and lacks valuable nutrients such as fibre, vitamins and minerals. However, there is also an ever-increasing fashion for being slim. In pursuit of a slender figure, young people, especially girls, often use extremely strict dieting regimes (Jeżewska-Zychowicz, 2004).

In contrast to these habits, proper nutrition should be based on meeting the needs of the body. To eat properly, foods of a particular type should be consumed in correct quantities in order to provide the appropriate nutrients to the body (Ciborowska, \& Rudnicka, 2007). 


\section{Methodology}

The aim of the study is to analyse high school students' comprehensive approach to caring for their own health, focused on the diagnosis of healthy behaviours regarding physical activity and a balanced diet in high school students aged 16-19 years old studying in Radom.

The analysis of literature indicates the importance of family in shaping eating habits and nutritional culture, as well as in establishing patterns connected with physical activity. At the same time, the peer environment is also conducive to leisure physical activity socialization and participation in sport.

The basic research question concerns the conditions of the study group's participation in leisure physical activities and the relationship between participation in physical activity and the practise of rational nutritional habits.

The study was conducted in VII Krzysztof Kamil Baczyński High School in Radom. The study involved 140 students. The first group consisted of 72 students from 16 to 19 years of age, and the second group consisted of 68 students from 16 to 19 years of age. The majority of respondents were residents of Radom.

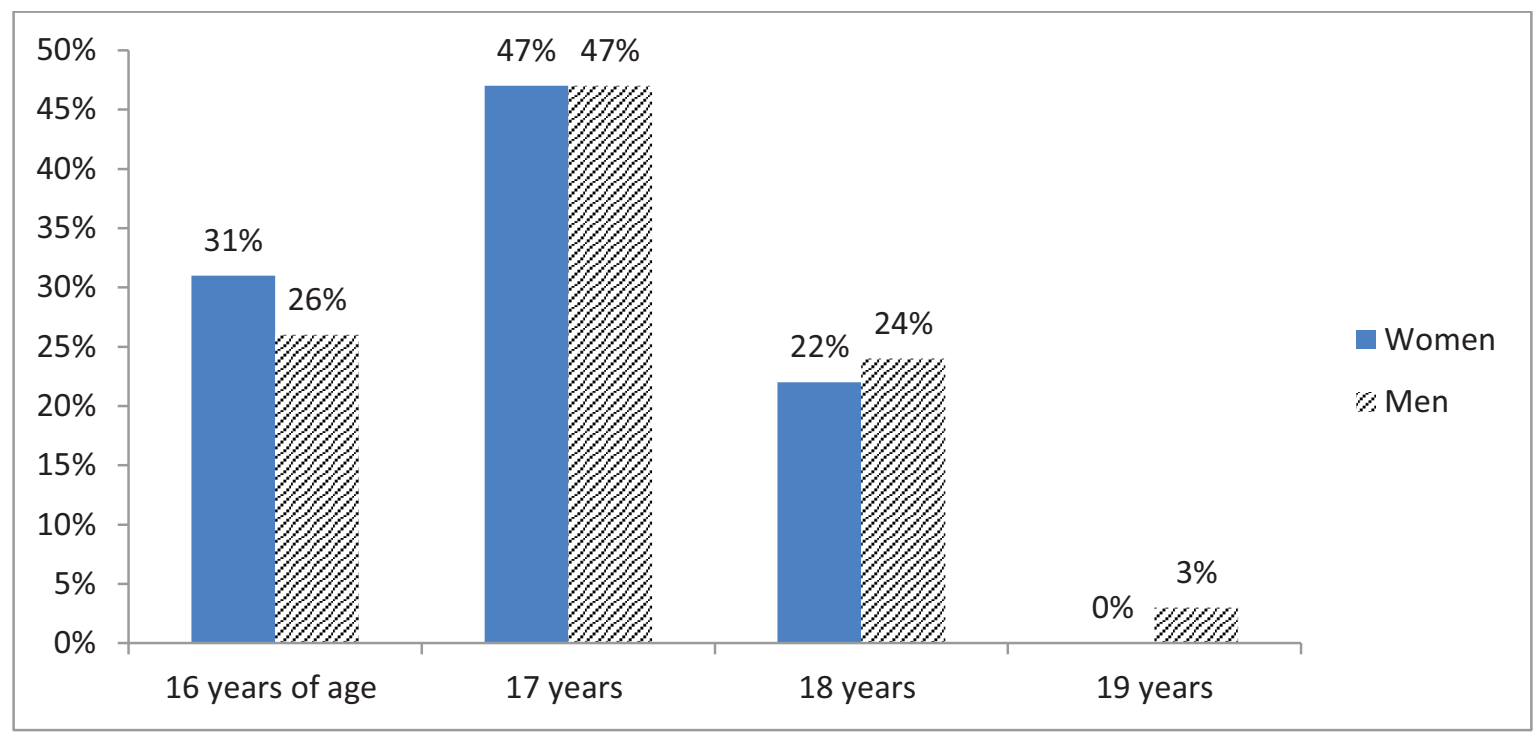

Figure 1. The age of the surveyed men and women Source: own study.

The most numerous respondents were 17-year-olds of both sexes. The groups of younger and older respondents were similar in size, with a slight predominance of 16-year-olds.

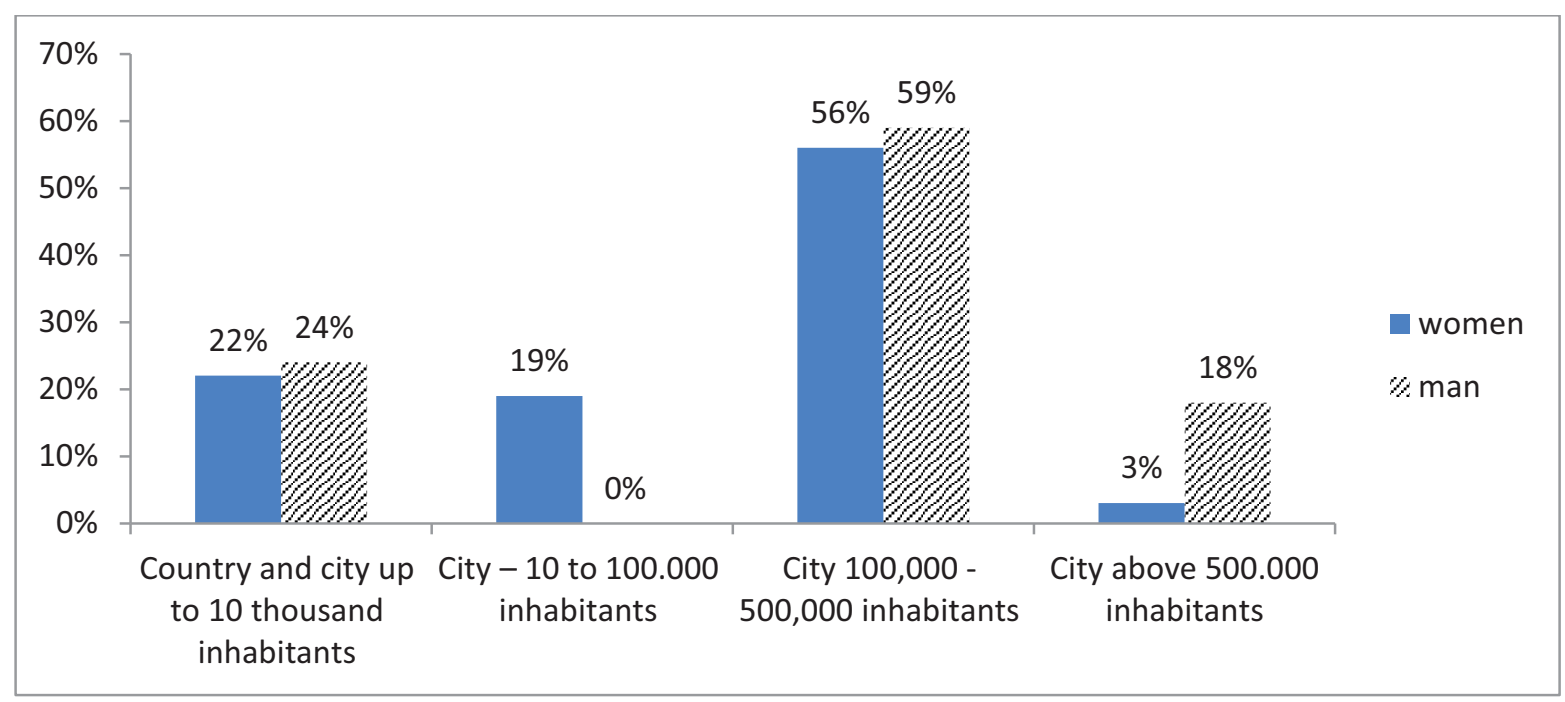

Figure 2. Population of respondents' reported cities of residence Source: own study. 
Slightly more than half of the respondents were residents of Radom, while the rest were young people living in villages and small towns. It is interesting that $18 \%$ of the men reported cities of over 500,000 residents as their place of residence.

\section{The results of the surveys}

The concept of caring for one's health can be interpreted individually, depending on the current needs of a person concerning health or pro-health behaviours. Many studies, however, demonstrate the importance of the three basic components of healthy behaviour. For example, K.J. Puchalski (2005) indicates that young working Poles (25-45 years old) appreciate nutrition most in building their immunity to non-infectious diseases, followed by physical activity and rest, coping well with stress and, finally, medical check-ups. This group undertakes preventive actions when in full health as well as when they start feeling the symptoms of an illness (39\% of respondents).

However, the essence of pro-health behaviour lies in undertaking actions which protect against noninfectious diseases before the first symptoms appear. The biggest problem is encountered in recognizing the conditions for engaging in relatively regular pro-health behaviours. Frequently, young adults learn the importance of preventive measures and understand how to take these measures, but never put them into a practical use. Previous research shows that only a small percentage of Poles lead a regular healthy lifestyle, systematically participating in sport, maintaing healthy nutrition and coping well with stress (Puchalski, 2005; Mogiła-Lisowska, 2010). Changes in priorities (although these priorities usually include "health" in their top three) often lead to a lack of focus on maintaining healthy behaviours for the sake of, for example, pursuing a career, acquiring material goods, etc., especially since these behaviours require systematic effort (for example, physical activity), consistency (rational nutrition) and a strong will (abstaining from stimulants).

In order to have a positive impact on health, physical activity must be implemented systematically, with the appropriate amount and intensity. The pro-health value of physical activity drops significantly when people take part in it only systematically. Many recent studies have shown that physical activity should be implemented 3 to 5 times a week in order to have a positive effect on health. High school students, who on a daily basis are immersed in their peer group and are obliged to participate in physical education classes, show regular participation in physical activities in large numbers (Fig. 3).

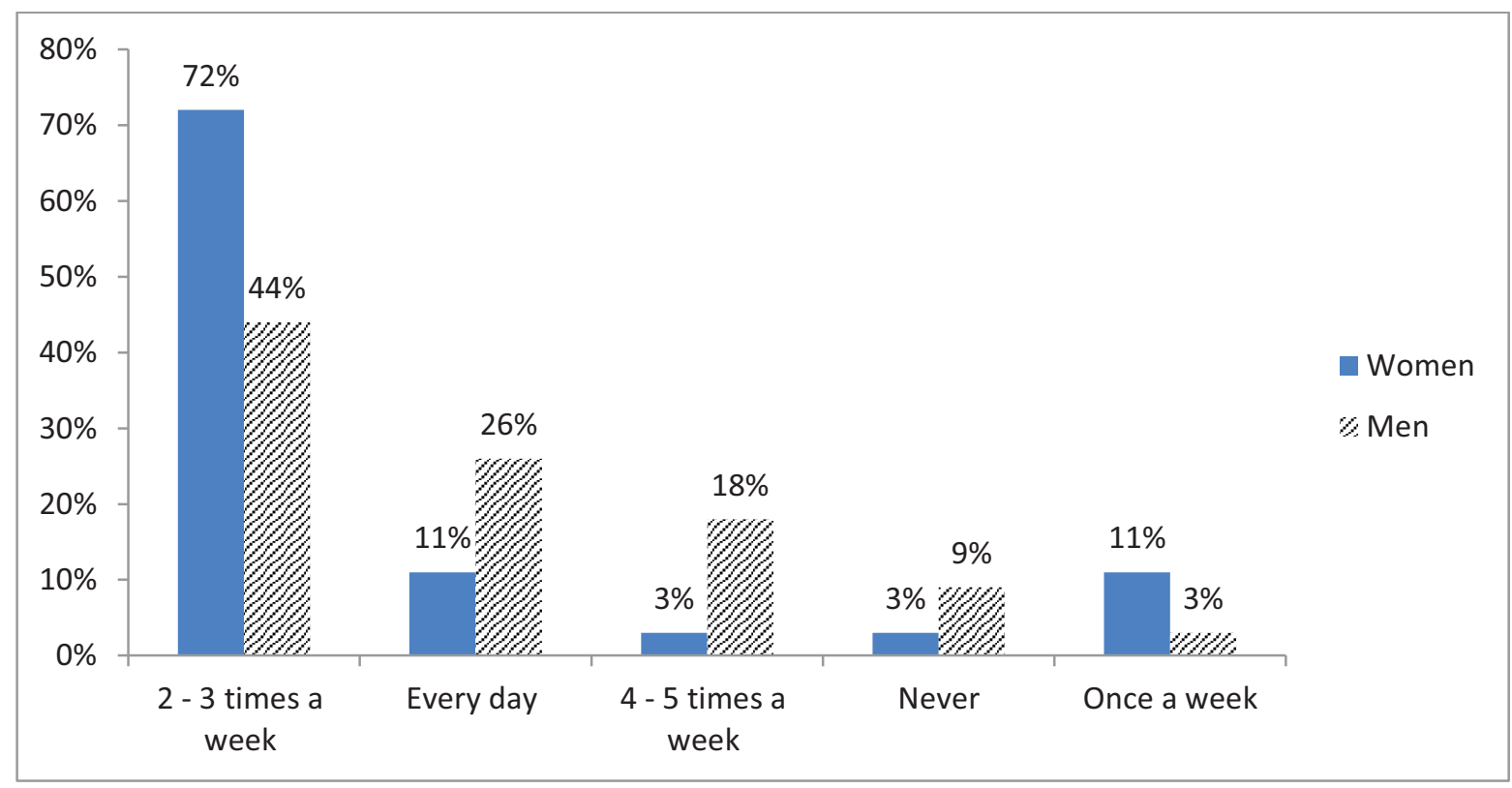

Figure 3. Participation in sport

Source: own study. 
The vast majority of the women and almost half of men took part in sports activities 2 to 3 times a week. The second group engaged in sport daily. The minimum healthy amount of physical activity is 4 to 5 times a week; this amount was undertaken by far more men than women from the studied group, but this percentage of students was still only $18 \%$.

A pro-health effect of physical activity is conditioned by its frequency as well as its appropriate intensity, volume and how it fulfils each individual's needs. The regularity of engaging in physical activity 5 days a week while also fulfilling other conditions is considered as systematic pro-health activity (recommendations of the WHO 2010).

The variety of forms of leisure activities provide many opportunities for participation in such activities. Because they require the company of peers, some activities encourage young people to participate, while others encourage relaxation or enhance cardiovascular fitness.

The challenges of modern times, which are characteristic for the development of civilization, mainly weaken the locomotor, circulatory and often the respiratory system. In order to promote health, physical activity should take into account individual genetic history while also balancing the negative impact of everyday behaviours. With the prospect of later professional work, the stress of daily duties and minimal amounts of physical activity throughout most of the day, young people should direct their interests towards aerobic or other activities that improve joint stability and mobilization of the joints, relaxing activities and exercises with weights (even those that use only body weight). Of course, the need to cooperate in a peer group is also important, especially as more and more employers pay attention to soft skills such as team work. It seems that in this case these skills could be developed by participating in team sports, which are still a common element of programs of physical education for young people.

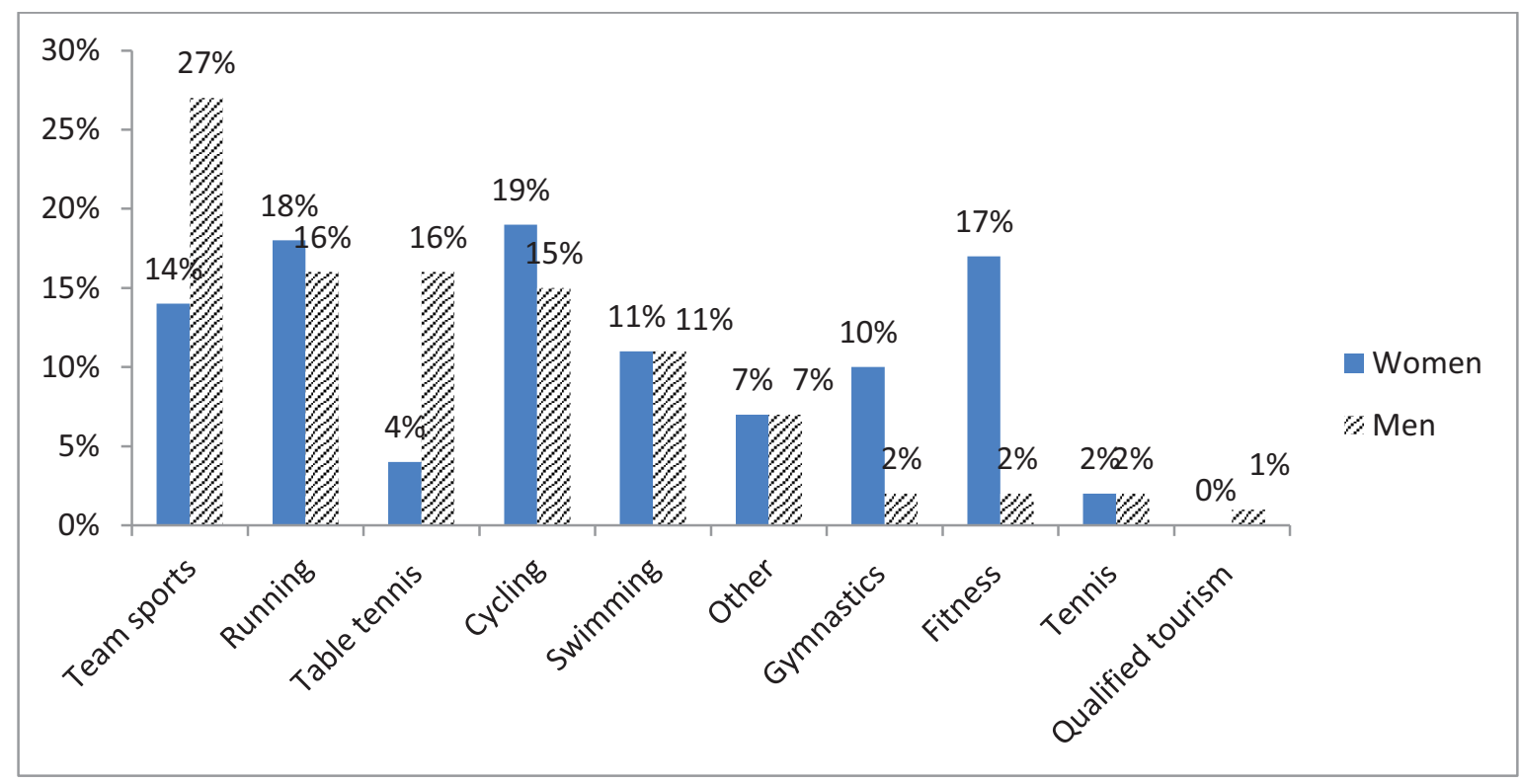

Figure 4. Interests of respondents regarding leisure and physical activities Source: own study.

Preferences in the selection of forms of activities were clearly differentiated by gender. Men definitely opted for team sports, running and tennis, while women chose cycling, running and fitness classes. Currently, cycling is one of the most popular forms of leisure and physical activity for Poles (Mogiła-Lisowska, 2010), and our respondents also declared a preference for this activity (Fig. 4).

Many research results justify the importance of primary socialization, especially in the process of shaping social roles. The human environment mobilizes to adopt the pattern of social roles, which is logical, as they are related to the needs of the environment that shape the individual. Early on, this function is performed 
by the family; however, appropriate and comprehensive development is achieved in correlation with the social environment, including the peer group. Socialization through sports, maintaining proper health and shaping the patterns of pro-health behaviours takes place through the influence of the immediate environment. We were interested in the strength of this impact in the case of our respondents' decisions to participate in physical activities (Fig. 5).

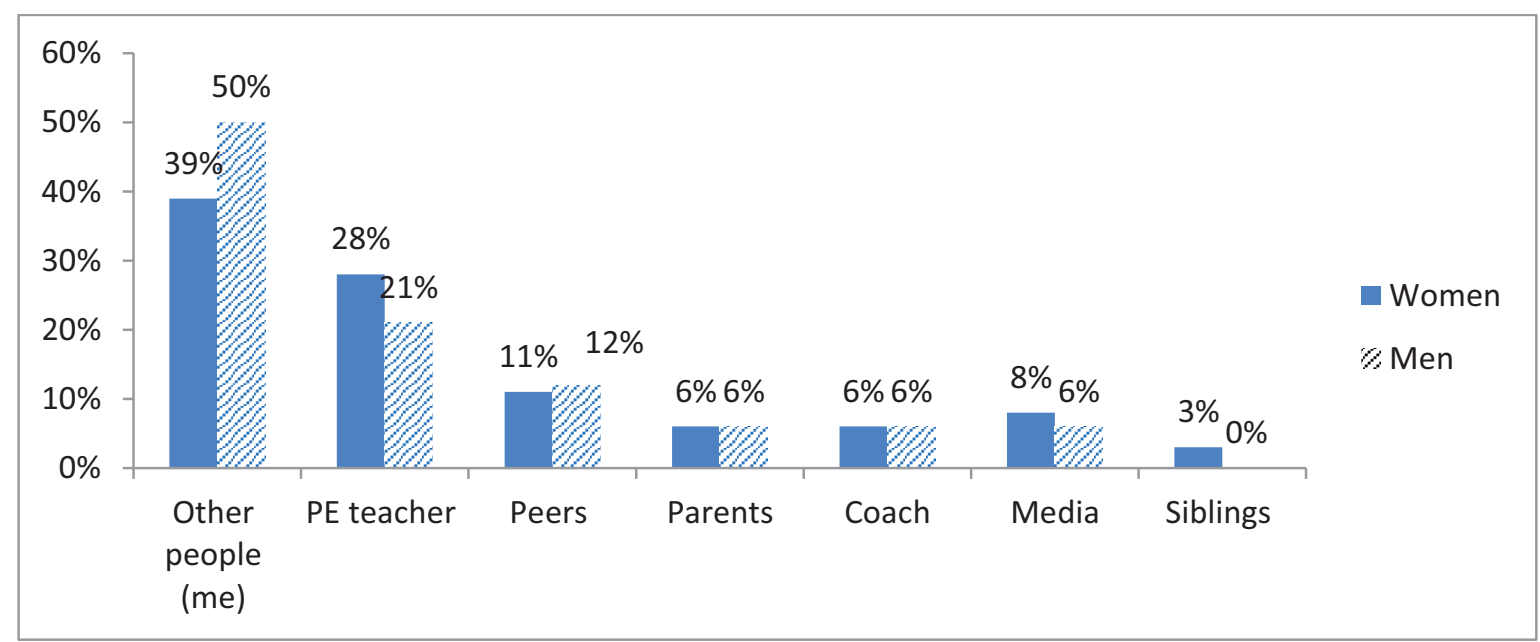

Figure 5. The influence of social groups on the physical activity of youth Source: own study.

Men more often mentioned social influences on decisions concerning physical activity. Half of them noted the involvement of other people in physical activity. Interestingly, the slightly larger group of women surveyed points to the impact of environmental education, namely the physical education teacher. In both groups, the influence of peer groups, parents and coaches is similar. Gender did not significantly differentiate the impact of socializing through sport in these environments.

The period of adolescence is characterized by an identity crisis and a gradual distancing from family care towards the peer group. However, one must not underestimate the impact of the family on sport-related choices. Today, it is mostly the family that socializes children regarding sport participation, and if the identity of a young person is not fully shaped by the family, they will look for patterns of behaviour (e.g. regarding physical activity) elsewhere. And here, the passive attitude of adults in shaping their own health is not conducive to the young generation building a solid foundation of health-related activities.

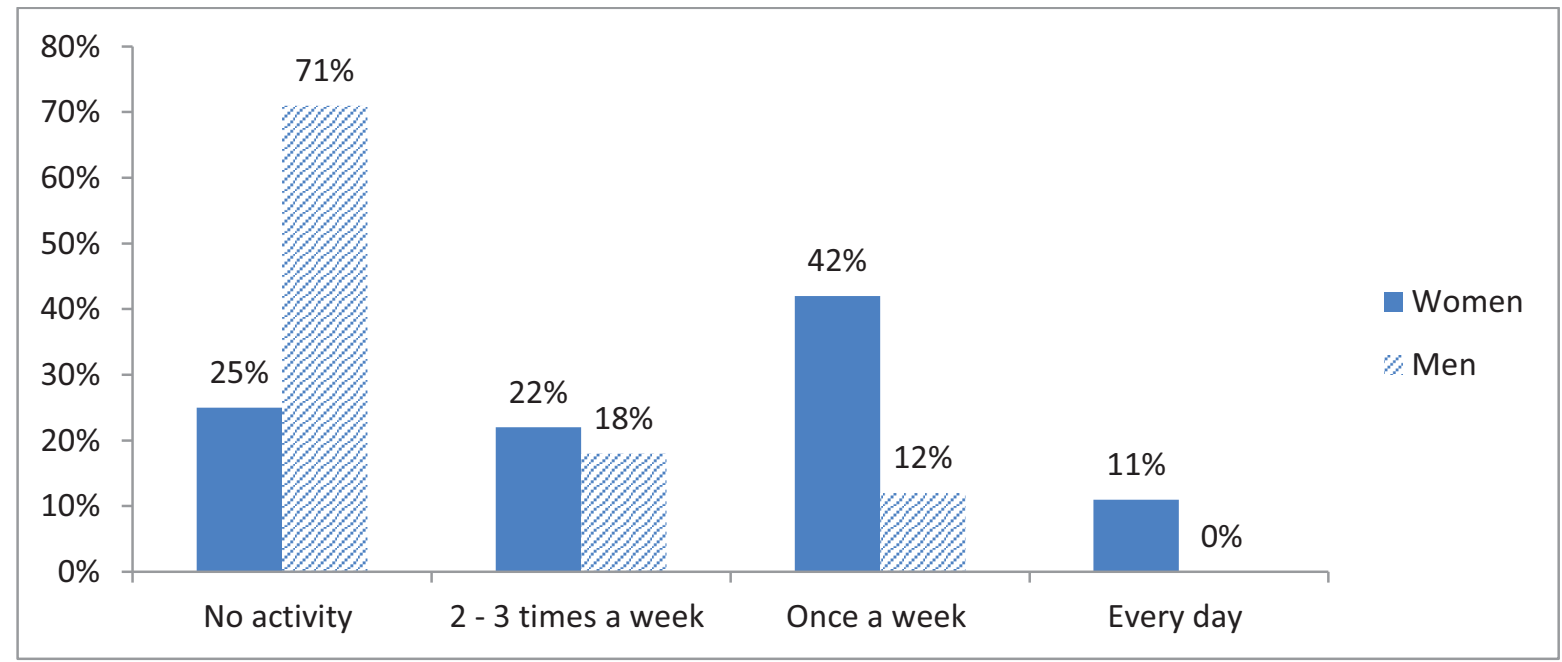

Figure 6. Participation in leisure physical activity of parents/guardians of the study group Source: own study. 
The researchers were interested in the impact of primary socialization on the participation of respondents in physical activities. The majority of the parents or guardians of the young people did not engage in physical activity or only participated in sport and leisure physical activities from time to time - once or twice a week. The pattern-making impact of the family does not seem to be very effective in the case of the studied group of high school students. Given that only $6 \%$ of respondents mentioned the influence of the family on their participation in sports, we get a picture of minimal environmental influence of primary socialization on the pro-health sport activities of respondents.

Health awareness directs and organizes the pro-health behaviour of people (Ratajczak, 1997). Of course, the way an individual thinks about his or her own health is conditioned by many variables, among them the three dominant ones mentioned by C. Herzlich (1973): a "superficial" perception of health, meaning a person becomes interested in their health only when it starts to fail; an understanding of health as a resource which can be managed, developed, maintained or subjected to individual strategies of care; and determining a person's own standards of health and referencing thinking about health to these individual standards. Following the thinking of C. Herzlich, we analysed our subjects' way of thinking about their eating habits. Taking into account individual standards of good, very good and bad nutrition, we observed how the problem is perceived.

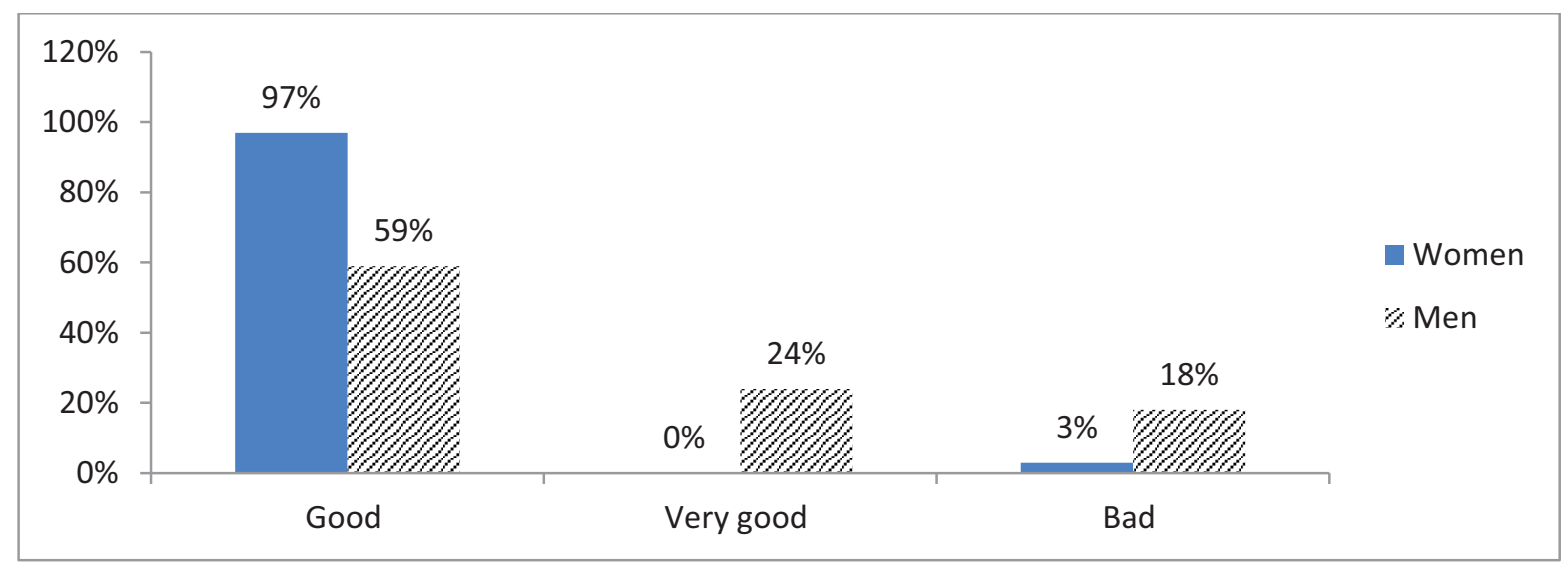

Figure 7. Individuals' evaluations of their own nutrition

Source: own study.

Nutritional self-assessment in conjunction with each successive declaration shows how consciously young people approach the problem of rational nutrition. Most of them, especially the women, estimated that they ate well. The men were also critical in the assessment of their nutrition, but about one-fourth of them claimed that they ate very well.

Verification of this self-assessment includes the number of meals consumed during the day. Many diseases and health ailments of modern society stem from eating unbalanced meals, skipping meals, eating in haste or overeating. Proper nutrition should consist of five balanced meals a day (Szczerek, 2002).

However, nearly half of the surveyed high school students consumed at least five meals a day, and nearly $10 \%$ skipped breakfast, second breakfast, afternoon tea and supper. Quite a large group ate them often or occasionally.

A very similar picture of daily meals was presented by the female subjects. Most of them ate at least five meals a day, and about $10 \%$ often selectively skipped the abovementioned meals. Similarly, a large group of women as well as men ate the above-mentioned meals only occasionally or rarely. 


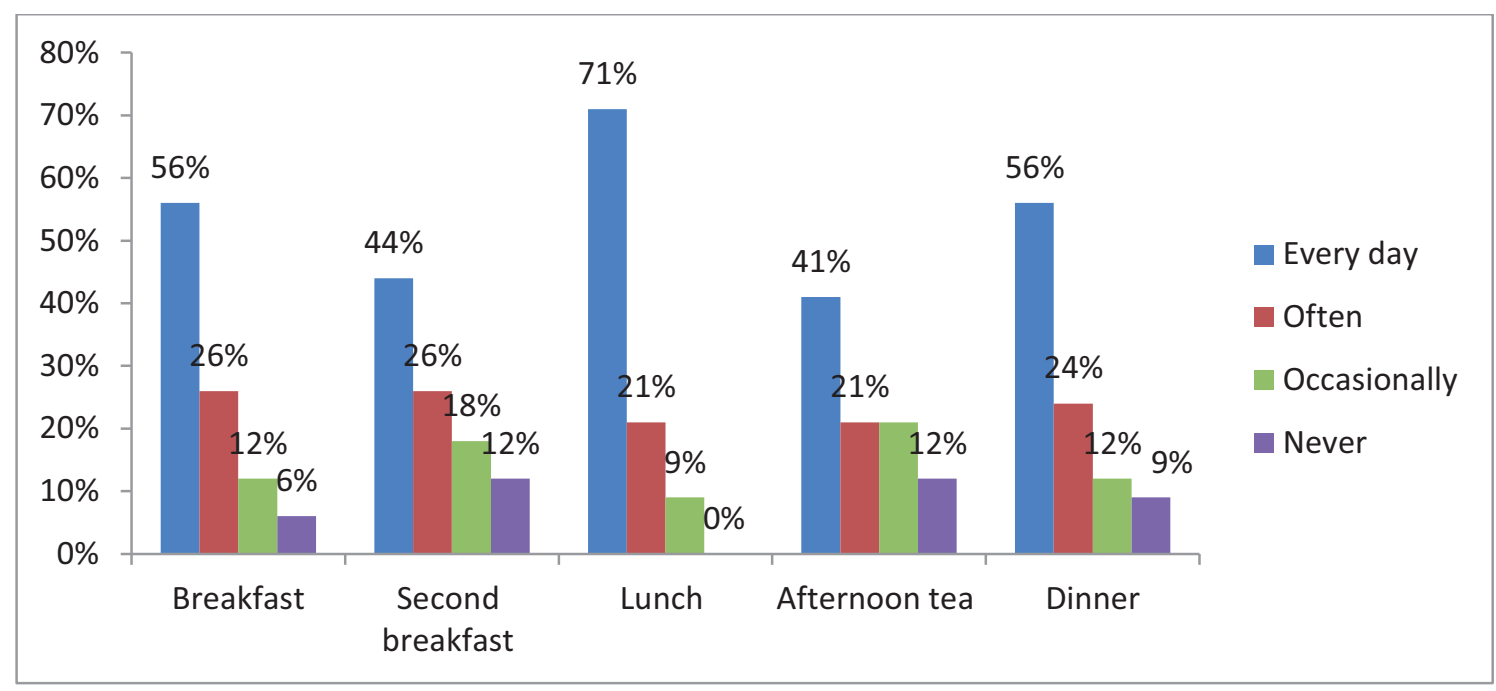

Figure 8. Daily intake of food by male respondents Source: own study.

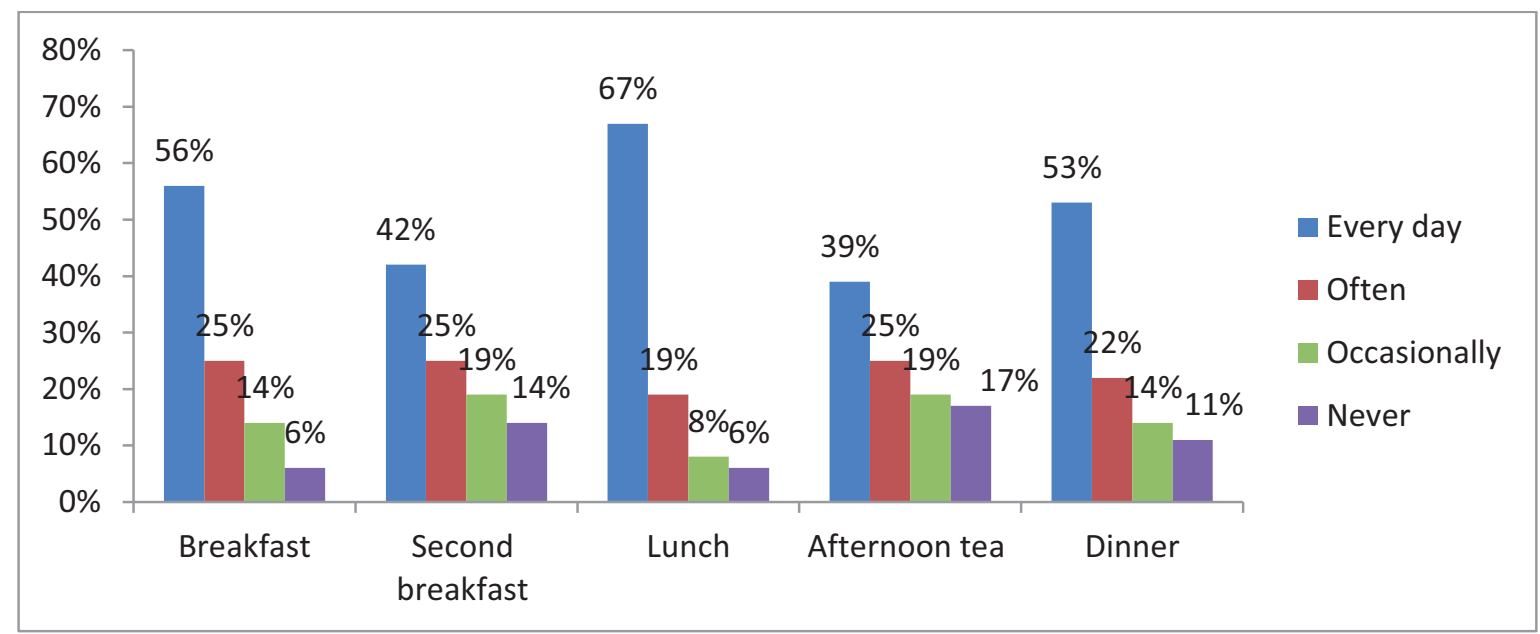

Figure 9. Daily consumption of meals by female respondents Source: own study.

These results show that young people have a fairly rational approach to nutrition. However, the problem of obesity is still present in our country. Today's children and adolescents are quite often characterized by obesity and weight problems. The main problem is caused by snacking between meals. In the case of children and young people, the snacks are mainly sweets and highly sweetened drinks. Obesity cannot be regarded only as a social problem. This is a relatively new non-infectious disease, and so it may also be considered a health problem.

A rational and healthy diet, devoid of unnecessary ingredients, excludes or minimizes the consumption of snacks between the five essential meals. Thirty-three percent of our subjects consumed sweets, a large group $(23 \%)$ of men ate chips and one-third of women consumed fruit as snacks. Only a small group (8\%) selected vegetables as a complement to fixed meals. 


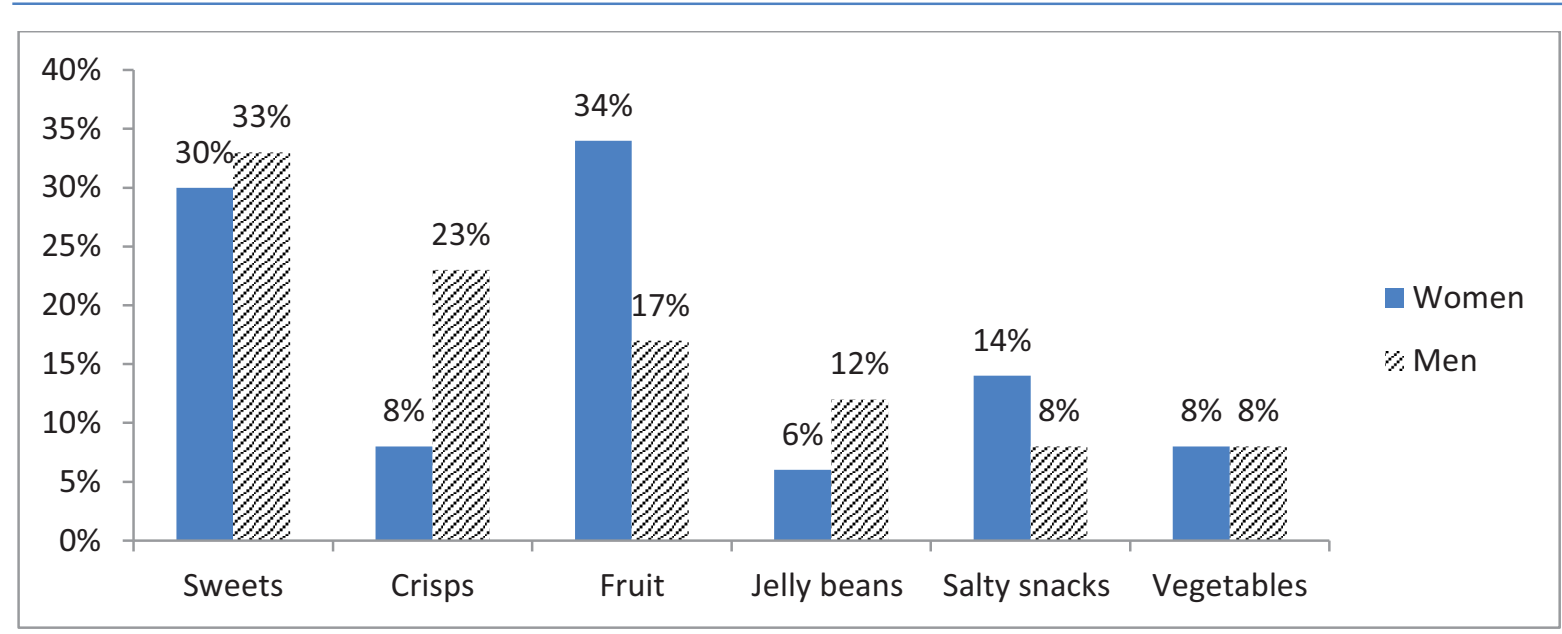

Figure 10. Snacking between meals Source: own study.

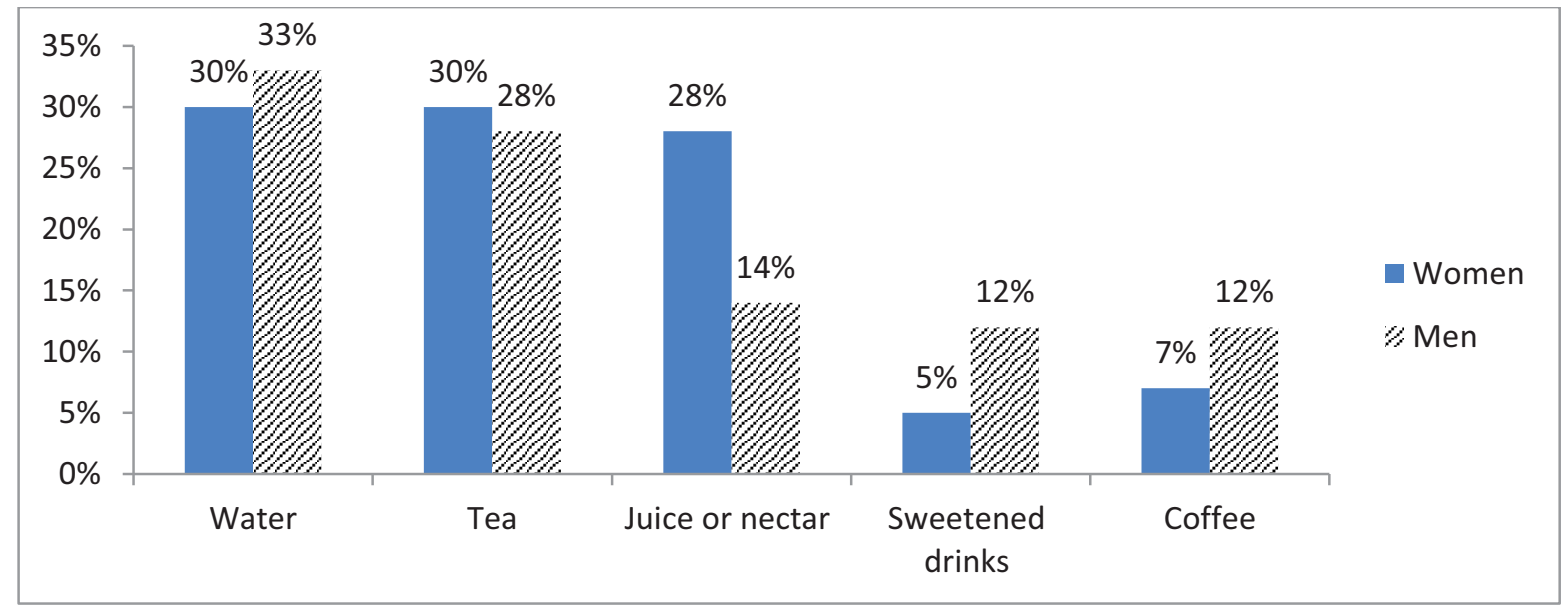

Figure 11. Most commonly consumed beverages

Source: own study.

The most popular drinks among the surveyed high school students were water and tea. Quite a large group of women said that they regularly drank juices and nectars. Interestingly, approximately two times more men than women drank sweetened drinks. Coffee intake was similar between the two genders.

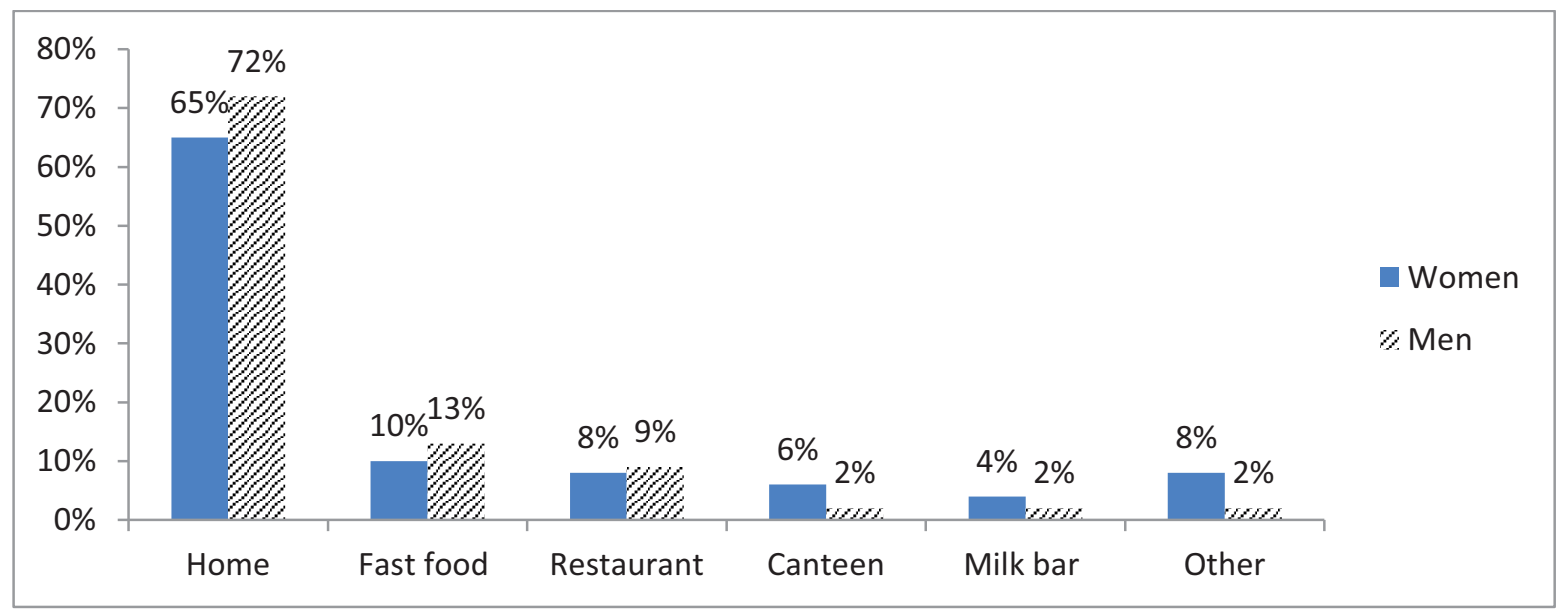

Figure 12. Where respondents eat Source: own study. 
Thanks to this study, we have managed to observe a very favourable situation regarding places where young people consume their meals. The vast majority of students ate their meals at home, and only a small group ate fast food, purchased in the city, on a regular basis. The high school students indicated that they rarely went to restaurants, canteens or bars.

\section{Conclusions}

The results of this study show that high school students from Radom are participants in regular physical activity, although it is not very intense during the week. According to various studies, in this ontogenetic period physical effort should be undertaken systematically up to 5 times a week. To maintain proper balance, daily physical activity of 10 minutes ( $80 \%$ max HR) is also recommended by the WHO, while Cooper recommends $3 \times 30 \times 130(\mathrm{HR} / \mathrm{min})$. One can also view daily physical activity needs from stance of burning calories - from 1200 to 2000 (Kozdroń, 2008, pp. 439-444).

The choice of leisure activities by young people is dubious. It is difficult to see a rational choice of forms of activity according to health burdens and threats. The youth use readily available and affordable forms of leisure activities, without paying attention to their pro-health values.

Half of the respondents fulfilled the healthy minimum (Frączak, 2003, p. 17; Ratajczak, 1997, p. 4) of eating five meals a day. Unfortunately, a large group of respondents is at risk of becoming overweight or obese. The popularity of eating unhealthy snacks does not carry a positive prognosis for the future in this respect (Saris, Blair, \& van Baak et al. 2003). The results also show the minimal impact of socialization towards a healthy lifestyle from the parents of the respondents, who are currently about 40 years of age. A similar situation has been demonstrated by I. Markiewicz-Górka (and others) concerning pro-health and preventive behaviours among students (2011, pp. 12-22).

Based on the obtained results, it can be assumed that there are links between making rational choices in the area of physical activity and diet, which is also indicated by T. Lisiecki et al. (2005, p. 17). Thus, promoting a so-called healthy lifestyle among high school students could bring beneficial effects in the form of increasing health potentials, including good physical condition.

\section{REFERENCES}

Bernstein, S.M., Morabia, A., \& Sloutskis, D. (1999). Definition and prevalence of sedentarism in urban population. American Journal of Public Health, 89, 862.

Bigddle, S., Sallis, J., \& Cavill, N. (1998). Young and active? Policy framework for young people and health-enhancing physical activity. London: Health Education Authority.

Bukowiec, M. (2009). Próba oceny systemu wychowania fizycznego w Polsce /Attempt to evaluate the system of physical education in Poland/. In K. Denek, K. Koszczyc \& W. Starościak (Eds.) Edukacja jutra /Education of the future/ (p. 326). Wrocław: Akademia Wychowania Fizycznego.

Brettschneider, W-D. (2004). Study on young people's lifestyles and sedentariness and the role of sport in the context of education and as a means of restoring the balance - Final report.

Carlsson, S., Andersson, T., \& Lichtenstein, P. (2007). Physical activity and mortality: Is the association explained by genetic selection? American Journal of Epidemiology, 166/3, 255-9.

Christopher, J.L., Murray, A.D., Lopez, B., Chin, D., \& Feehan, K.H. (2006). Estimation of potential global pandemic influenza mortality on the basis of vital registry data from the 1918-20 pandemic: A quantitative analysis. Lancet, 368, 2211-2218.

Chromiński, Z. (1987). Aktywność ruchowa dzieci i mlodzieży/Physical activity of children and youth/. Warszawa: Instytut Wydawniczy Związków Zawodowych.

Ciborowska, H., \& Rudnicka, A. (2007). Dietetyka - żywienie zdrowego i chorego czlowieka /Nutrition of the healthy and the ill/. Warszawa: PZWL. 
Drabik, J. (1995). Aktywność fizyczna dzieci, młodzieży $i$ dorostych /Physical activity of children, youth and adults/. Gdańsk: Akademia Wychowania Fizycznego.

Dziubiński, Z., \& Krawczyk, Z. (Eds.). (2011). Socjologia kultury fizycznej /Sociology of physical culture/. Warszawa: Akademia Wychowania Fizycznego.

Fletcher, G.F., Balady, G.J., \& Amsterdam, E.A. (2001). Exercise standards for testing and training. A statement for healthcare professionals from the AHA. Circulation, 104, 1694-1740.

Frączak, B. (2003). Charakterystyka sposobu odżywiania młodzieży klas maturalnych liceum ogólnokształcącego /Characteristic features of the diet of high school graduates/. Żywienie Człowieka. Metabolizm /Human nutrition. Metabolism/, 7, 12-16.

Garza, A.A., Ha, T.G., \& Garcia, C. (2004). Exercise, antidepressant treatment and BDNF mRNA expression in the aging brain. Pharmacology Biochemistry and Behavior, 77, 209-20.

Grzywacz, T.S. (2008). Metabolizm energetyczny chłopców w wieku okołopokwitaniowym- wpływ treningu fizycznego /Energy metabolism of boys in puberty - the influence of physical activity/. PhD thesis, Akademia Wychowania Fizycznego, Gdańsk, Poland.

Handbook for Canada's physical activity guide to healthy living (1998). Health Canada, Ottawa.

Herzlich, C. (2004). Health and illness: A social psychological analysis. European Association of Experimental Social Psychology by Academic Press, 01.01.1973, 159.

Health behaviour in school-aged children (HBSC) study: International report from the 2013/2014 survey. (2016). Copenhagen, WHO Regional Office for Europe, Health Policy for Children and Adolescents, No. 7.

Jakicic, J.M., \& Otto, A.D. (2006). Treatment and prevention of obesity: What is the role of exercise? Nutrition Review, 64, 57-61.

Jakicic, J.M., Otto, A.D., Polzien, K., \& Davis, K.K. (2007). Physical activity and obesity. In R.F. Kushner \& D.H. Bessesen (Eds.) Treatment of the obese patient (pp. 311-320). New Jersey: Humana Press Totowa.

Jeżewska-Zychowicz, M. (2004). Wpływ czynników społecznych na zachowania żywieniowe /Influence of social factors on nutritional behaviour/. Żywienie Człowieka. Metabolizm/Human nutrition. Metabolism/, pp. 78-85.

Kalecińska, J. (2005). Rola rodziny w kształtowaniu zdrowego stylu życia młodego człowieka w społeczeństwie postindustrialnym - główne kierunki problemu w literaturze /The role of the family in shaping healthy lifestyles of young people in the post-industrial society/. In W. Siwiński, R.D. Tauber \& E. Mucha-Szajek (Eds.), Hotelarstwo, Rekreacja, Turystyka. Kierunki przemian $w$ świecie postindustrialnym /Hospitality, leisure, tourism. Changes in the post-industrial world/. Poznań: Wydawnictwo WSHiG.

Kozdroń, E. (2008). Zalecenia dotyczące poprawy sprawności adaptacyjnej człowieka starszego: promocja zdrowego starzenia się /Suggestions for improving adaptive skills of the elderly: Promotion of healthy aging/. In W. Siwiński et al. (Eds.), Wspótczesne tendencje w rekreacji i turystyce /Contemporary tendencies in tourism and recreation/ (pp. 439-444). Poznań: Wydawnictwo Wyższej Szkoły Hotelarstwa i Gastronomii.

Kozłowski, S., \& Nazar, K. (1995). Wprowadzenie do fizjologii klinicznej /Introduction to clinical physiology/ (pp. 3436). Warszawa: PZWL.

Królikowska, B. (2002). Bariery ograniczające aktywność rekreacyjno - sportową młodzieży szkolnej w województwach opolskim i śląskim /Barriers to leisure and sports activities of school children in the Opolskie and Silesian Voivodeships/. In Z. Żukowska \& R. Żukowski (Eds.), Sport i zdrowie w edukacji globalnej /Sport and health in global education/. Warszawa.

Książek, P. (2006). U.S. health care. A different perspective. Polish Journal of Public Health, 116(4), 1-3.

Leon, A.C., Rodriguez-Perez, M., \& Rodriguez-Benjumeda, L. (2007). Sedentary lifestyle: Physical activity duration versus percentage of energy expenditure. Revista Española de Cardiología, 60, 244.

Lichtenstein, A.H., Appel, L.J., \& Brands, M. (2006). Summary of American Heart Association diet and lifestyle recommendations, Revision 2006. Arteriosclerosis, Thrombosis, and Vascular Biology, 26, 2186-91.

Lisiecki, T., Wilk, B., \& Walentukiewicz, A. (2005). Prozdrowotny styl życia. Uwarunkowania spoteczne /Healthy lifestyle and its social conditions/ (p. 131). Gdańsk: Akademia Wychowania Fizycznego.

Manson, J.E. (2004). The escalating pandemics of obesity and sedentary life style. A call to action for clinicians. Archive International Medicine, 164, 249-58. 
Markiewicz-Górka, I., Korneluk, J., \& Pirogowicz, I. (2011). Aktywność fizyczna oraz wiedza studentów Akademii Medycznej we Wrocławiu na temat jej roli w profilaktyce chorób - badania ankietowe /Physical activity and the knowledge on its role in preventing diseases among Medical Academy students - survey results/. Family Medicine \& Primary Care Review, 12, 70-73.

Maszczak, T. (2009). Wychowanie fizyczne i zdrowotne w służbie edukacji /Physical culture in the service of education/. In K. Denek, K. Koszczyc \& W. Starościak (Eds.), Edukacja jutra /Education of the future/ (p. 88). Wrocław: Akademia Wychowania Fizycznego.

Mogiła-Lisowska, J. (2010). Rekreacyjna aktywność ruchowa dorostych Polaków: uwarunkowania i styl uczestnictwa /Leisure physical activity of adult Poles - conditions and participation styles/ (pp. 13-14, p. 101). Warszawa: Akademia Wychowania Fizycznego Józefa Piłsudskiego w Warszawie.

Oja, P. (2001). Dose response between total volume of physical activity and health and fitness. Medicine \& Science in Sports \& Exercise, 33, Suppl., 428.

Pedersen, B.K., \& Saltin, B. (2006). Evidence for prescribing exercise as therapy in chronic disease. Medicine \& Science in Sports \& Exercise, Suppl. 1, 3-63.

Prochaska, J.J., Salis, J.F., \& Long, B. (2001). A physical activity screening measure for use with adolescents in primary care (pp. 554-559). Archives Paediatric Adolescent Medicine.

Puchalski, K.J. (2005). Opinions of Polish occupational medicine physicians on workplace health promotion. International Journal of Occupational Medicine and Environmental Health, 7-8, 32-44.

Ratajczak, Z. (Ed.) (1997). Promocja zdrowia: psychologiczne podstawy wdrożeń /Promoting health: psychological basis for implementation/ (pp. 30-108). Katowice: Wydaw. Uniw. Śląskiego.

Sadowska, M. (1992). Spontaniczne formy aktywności ruchowej dzieci i młodzieży oraz wczesna inicjacja w procesie wychowania do kultury fizycznej /Spontaneous forms of physical activity of children and youth and early initiation of physical education/ (pp. 1-142). Warszawa: Akademia Wychowania Fizycznego Józefa Piłsudskiego w Warszawie.

Saris, W.H.M., Blair, S.N., \& van Baak, M.A. (2003). How much physical activity is enough to prevent unhealthy weight gain? Outcome of the IASO $1^{\text {st }}$ Stock Conference and consensus statement. Obesity Review, 4, 101-114.

Sozański, H. et al. (Eds.) (2003). Kierunki doskonalenia treningu i walki sportowej /Directions for perfecting trainings and sports competition/ (pp. 82-310). Warszawa: Akademia Wychowania Fizycznego Józefa Piłsudskiego w Warszawie.

Srokosz, W. (2005). Racjonalnie przygotowujmy uczniów do dbałości o swoje zdrowie /Rationally preparing pupils for a healthy lifestyle/. Annales Universitatis Mariae Curie-Skłodowska, 42.

Szymańska, J. (2002). Programy profilaktyczne: podstawy profesjonalnej psychoprofilaktyki /Prevention programmes: basics of professional psychoprophylaxis/ (pp. 16-114). Warszawa: Centrum Metodyczne Pomocy PsychologicznoPedagogicznej.

Van Baak, M.A., \& Saris, W.H.M. (2005). Exercise and obesity. In P.G. Kopelman, I.D. Caterson \& W.H. Dietz (Eds.), Clinical obesity in adults and children (pp. 363-379). Blackwell Publishing.

Varo, J.J., Martinez-Gonzalez, M.A., \& de Irala-Estevez, J. (2003). Distribution and determinants of sedentary lifestyles in the European Union. International Journal of Epidemiology, 32, 138.

Wadden, T.A., Butryn, M.L., \& Wilson, C. (2007). Lifestyle modification for the management of obesity. Gastroenterology, 132, 2226-2238.

Warburton, D., Nicol, C.W., \& Bredin, S. (2006). Health benefits of physical activity: the evidence. Canadian Medical Association Journal, 174, 801-9.

Warburton, D., Nicol, C.W., \& Bredin, S. (2006). Prescribing exercise as preventive therapy. Canadian Medical Association Journal, 174, 961-74.

Wing, R.R. (1999). Physical activity in the treatment of the adulthood overweight and obesity: current evidence and research issues. Medicine \& Science in Sports \& Exercise, 31, 547-552.

World Health Organization (2010). World health report.

Woynarowska, B. (2003). Rozwój fizyczny dzieci i młodzieży /Physical development of children and youth/ (pp. 13-22).

Warszawa: Wyd. Lekarskie PZWL. 
AUTHOR'S ADDRESS: Jolanta Mogiła-Lisowska

Chair of Recreation

Josef Pilsudski University of Physical Education in Warsaw

Marymoncka 34

00-968 Warsaw, Poland

E-mail: jolantamogilalisowska@wp.pl

Received: 25 May 2016; Accepted: 14 August 2016 